\title{
Role of Media in Creating a Peaceful Electoral Process: A Case of Sierra Leone's General Elections of 2018
}

\author{
Dr. Ibrahim Seibure \\ Central China Normal University, Wuhan, P.R.China \\ Email:ijsei69@yahoo.com \\ Alhaji Mustapha Javombo \\ Institute of Public Administration and Management, University of Sierra Leone, Freetown, Sierra Leone
}

\begin{abstract}
Recently the task of the media in conducting elections has been an issue of great concern globally. Its impact has increased immensely and investigators are obliged to agree on the degree and magnitude of the media influence in creating a peaceful election. The aim of this study was to evaluate the responsibility of media in creating a peaceful election, with reference to the 2018 pre and post-election violence in Sierra Leone. The specific objectives were to establish the media accessibility level and the various modes of media coverage; to establish the extent to which media advocated for peace or violence during the 2018 general elections in Sierra Leone. Extensive literatures were analyzed to explain media roles and to develop a foundation for the present research. The research adopted both qualitative and quantitative research methodology where a descriptive research design and random stratified sampling method with a sample size of 388 respondents was used. Primary data was obtained via questionnaires and in-depth interviews analyzed and presented in various forms. The study found out that media performed both conflict escalation and peaceful tasks during the 2018 general elections. Some of the negative media roles include encouraging hate speech, misrepresentation of information, and incitement. Some positive roles include conducting civic education, preaching peace, fair coverage of political rallies, and fair reporting of contentious matters during peace negotiations. The study recommends stringent measures for negative journalism while highlighting the merits of peace journalism.
\end{abstract}

Keywords: Media, Media Role, 2018 General Elections, Electoral Process, Sierra Leone.

\subsection{Introduction}

The recent election of Julius Maada Bio as president of Sierra Leone has been hailed globally as a historic transmission of power for Sierra Leone with media playing a significant role in the fairness of the election. The 2018 General Elections in Sierra Leone shall go down in the country's records of elective procedure as the most historic and outstanding. In the author's estimation, shall ever remain so for a long time in different respects: firstly, they were devoid of a lot of intentional violence particularly, in their post-election experience and analyses. Secondly, it is what many analysts have been concentrating on, and the elections led to the comprehensive defeat of incumbents nationwide (Udensi, 2018).

The role of the media in every given society is majorly to educate, inform and enlighten. It is expected that, where these roles are efficiently carried out, elections are likely to be free and fair. Mass communication has been a strategic instrument in the struggle for hegemony, both within the nation and globally ( Jalloh, 2012, p5). The desire and the need for information dissemination and also the desire for social groups to dominate and conquer their respective society open the importance of media to any community (Jalloh, 2012).

The working definition of the media we would like to adopt for this paper is "Mass Media" it includes social media even though scholars like Yaqub and Sani (2015), strongly argue that social media is not yet fully covered by a majority of Sierra Leone populous. As a consequence, a reference to the mass media in the paper is premised on the conservative understanding of the phrase. Clearly stated, mass media is defined as all forms of communication that are both modern and are, at least, sophisticated and technologically driven. These would consist of the newspapers and electronic mass media institutions such as the newspapers and the television stations.

In the 1960 s there was a stout belief in the power of mass media to propagate ideas on social change directly. Calls to improve mass communication systems of underdeveloped countries were made as a reaction to the UN General Assembly Report implying that $70 \%$ of the world's population had limited access to information. Said calls came with the requirement to write a guide on how developing countries could optimise the power of the mass media for development. Wilbur Schramm accepted the task where he was later connected with the Stanford Institute of Communication Research. The product was his book: 'Mass Media and National Development: The Role of Information in the Developing Countries". This book implicitly argues that the nation-state promoting development is useful and vital, and thus the media can enhance the process.

Schramm argues that the media highly entice people to change. However, media can only exclusively do so 
much when it comes to persuading people in making a first attitudinal change. The book covers campaigns regarding agriculture, health, literacy and formal education using mass media. That is to emphasise the power of mass media in influencing significant behavioural change in society (Schramm, 1964). That can be further understood by looking at (Kamara, 2013), where he pointed that due to nature of Sierra Leone population, diversity, religious associations, political alignments, social alliances, ethnic segmentation among others, mass media in Sierra Leone serve as a significant system of communication across such ( Kamara, 2013, p3). He further emphasized, saying that, the issue of diversity in Sierra Leone can be seen clearly in it media where "issues like ideology, religion, regionalism ethnicity, and politics of resources allocation, power sharing among others are debated openly in newspaper pages and airways of broadcast stations" ( Kamara, 2013, p4). That is to say media in Sierra Leone serve an essential role in ironing national issues. Other scholars like Ibraheem, et al., (2013), assert that media arbitrate; they do not stand self-governing of a given social system but rather provide networks of communication between its elements. That is to say the media act as a platform through which people express their views in society.

Consequently, studying the diverse scholarly understanding about the media we can conclude the duty of media in community by referring to Ekeayumwu, (2007), "the media exist as an organ of information sourcing and dissemination, educational promotion, surveillance, social enlightenment and mobilization" these tasks distinguishes the media as an essential link aspect in the relationship between the government and the citizens and make them a pillar in societal growth and development.

It is a useful concern that should pave the way for fruitful avenues for policy formulation through research to enhance the shared-body of knowledge on the media's role in the promotion of peaceful electioneering processes in post-conflict African nations. Arguably, the gulf in the African media's literature about the media's functionality concerning elections is amplified by the realities that the sector is still evolving. Additionally, the continent's intellectual development is fraught with small opportunities for publications, an inadequacy of professional researchers, and lack of financial resources to fund ground-breaking studies and the deficiency of the necessary logistics for research (Alozie, 2007).

The significance of this research cannot be overemphasised. The election also witnessed unprecedented mass media coverage ever in the history of elections in Sierra Leone. The mass media were inundated with not only political advertisements but also news analysis, news features, news stories, editorials, opinion articles, predictions among other media genre to the extent that on a daily basis before the election in March 2018, the mass media (print and electronic) became the mass educator that they are. This is because the mass media became not only the rallying point of accumulating people's views but also the barometer with which political parties assess their popularity.

The media and its personnel, in addition to the existing professional code of ethics, received several advisory guidelines and laws that are in line with best practices on reporting elections and electioneering issues.

Widely circulated in the industry, the guidelines sought to enforce professional handling of information in line with the code of ethics that emphasize truth, balance, fairness, and equity to all parties and candidates. In very few cases, in house brainstorming sessions were internally held in the media houses. The Sierra Leone National Broadcasting Corporation provided an elaborate Guideline on Political Reportage. The media also got some instructional guides from the African Young Voices (AYV), in Sierra Leone, Independent National Electoral Commission and others.

However, the availability of these guides did not significantly prevent professional breaches in the broadcast media particularly in those owned by the state governments and few private stations in handling campaigns and particularly the elections. For instance, in the 2007 and 2012 elections, Independent Observers had delivered mixed assessments on the conduct of the media in the entire electoral exercise. One of such observer groups, the Transition Monitoring Group, an amalgam of civil society organizations, reported that the election was significantly and widely covered by the media. They have individually and collectively devoted considerable space and air time to the process. In the end, while some sections of the press were said to have tried to communicate ethically, professionally and in line with the Electoral Act, many others were accused of bias, denial of access and acts of professional misbehavior.

In lieu of the above, the primary purpose of the study was to analyse the role played by the media before, during and after the 2018 general elections in Sierra Leone.

\subsection{Objective of the Study}

The following specific objectives guided the research:

- To establish the media accessibility and the various types of media coverage within Sierra Leone during the 2018 general election.

- To establish the extent to which media advocated for peace or deescalated violence during the 2018 general elections in Sierra Leone

- To suggest policy reforms that will ensure the media enjoys its due privileges 
Following the introduction, the rest of the paper is structured as follows; section two focuses on the literature review to establish a foundation upon which the research is built, section three presented a brief methodology that was adopted in carrying out the research while section four presented the results and findings made during the research. Section five concludes the paper and offers recommendation to further improve on the initiatives being discussed.

\subsection{Literature Review}

It is a fact that there is hardly a scholarly work that could be completed without making reference or drawing from the ideas of similar works that already exist. As researchers continue to build their ideas on previous works, the knowledge bank continues to flourish. The present study is not an exception.

This paper, among other things, explored the current literature on media as well as the electoral process to ascertain the shared body of knowledge in the discipline. It further evaluated a case for an evolving view that proposes to improve the frontiers of the subject generally in Africa and particularly in Sierra Leone (Okigbo, 2000; Sachs, 2005) ${ }^{1}$. Regardless of Africa's gradual strides towards development, ethnic-regionalism, corruption, poverty and illiteracy, epidemics, tyranny and armed conflicts, remain the stereotypical factors that establish the 'lenses' and 'frames' that tinted the Western media's coverage of issues and events in the continent (Shaw, 2007, 351-371, 2009: 39-47, 2012: 105 -121, Ankomah, 2001) ${ }^{2}$. The Western media's illustration of Africa in international relations is yet to replicate the real picture of the continent.

Therefore, the responsibility of the African press towards the rest of the globe is to portray a more sensible perspective of Africa (Nwokeafor, 2000). Although most countries in Africa have embraced democracy and there are indications that in post-conflict African states, the media and electioneering processes, despite their drawbacks, have been carefully observing and holding post-conflict governments accountable to their electors (Macauley, 2012: 47-51, Kargbo, 2010, Okigbo, 2002). Nevertheless, a lot is yet to be done by Western media analysts and African scholars (through empirical research) to determine how the media have been instrumental in the campaign against impunity as well as building peaceful electioneering processes in the continent.

The mass media have been fundamental pillars in the Sierra Leone democratic system. Individually, they have played critical roles in the electoral process by acting as significant sources of information, providing essentially costless and reliable details leading to a more balanced education and opinion formation among the voting public. The connection between the politician and mass media should, therefore, be contextualised from the point of view of the politician who wants to win an election, whether by hook or by crook. In the process, they would work hard to grab the attention and engagement of the audience that the mass media controls. (Kamara, 2013).

So by critically examining the above assertion, somehow, this logic may have to be extended to the concern of the mass media institution, particularly the owner. The primary benefit of mass media, majorly the commercially oriented ones, is to remain in business and make money since mass media business is not a charitable organisation by any stretch of the imagination. They further said that the only caveat one would, however, have to enter into here is that as an organisation that has a financial interest; it must at the same time be conscious and appreciative of the mores of the society in which it operates. Also, it should be able to reflect those mores as when it enters into the symbiotic (business) relationship with the politicians. The same warning, naturally, should apply to the (Sierra Leonean) politicians, as well. In other words, the politician must also realize that there is always the highest rank of societal solidarity, which makes it necessary that the fight for power against other political opponents should not be a license for mischief, national destabilization and anarchy.

Therefore, in examining the role of the mass media during the 2018 General Elections in Sierra Leone, what comes out clearly is the utter neglect of not only the cardinal principle of journalistic practice, by all the stakeholders-the politicians and mass media institutions and their owners but also there was a palpable assault on the behaviour about societal solidarity and harmony. For example, blatant lies were issued out by the organizations, as much as the politicians so long it was overlooked that they would score a huge political point. Before we list the glaring negativities that characterized the political campaigns and electoral processes, it is pertinent to note that the ultimate goal for the acquisition of political power is not for its own sake. It is, however, to attain the higher and nobler objective of rendering services as well as adding value to the existential conditions of the people that may have given the responsibility to the political leadership. Simply put, acquisition of power is for national growth and development.

The paper critically looked into the role of the mass media organizations in Sierra Leone during the 2018 General Elections. The study stressed the pivotal role elections play in democratic politics and welcomed the gradual but steady progress being made in that direction. The research was exultant that the performance of the election administration body was acknowledged by all and sundry, of course, the excellent performance should be

\footnotetext{
${ }^{1}$ See, Okigbo, 2000; Sachs, 2005

${ }^{2}$ See Shaw, 2007, 351-371, 2009: 39-47, 2012: 105 -121, Ankomah, 2001
} 
regarded as work in progress, which, by definition, could and should be bettered the next time around. The greatest challenge to the organization and conduct of elections in general and, for the media, in particular, has been the erratic attitude of many of the stakeholders.

This attitude had permeated into the general society as evidenced in the perceptions of the people. The intolerant behaviors of politicians, the absence of internal political party democracies, weaknesses of institutions like the National Electoral Commission (NEC), security agencies, etc. quite often betrayed desperation, illegality and dishonesty aptly captured, reinforced and represented by the media.

The media had repeatedly encountered mindsets, attitudes and habits that had affected their performance in the electoral process. As argued by (Waisbord, 2016), "election mindsets are particularly consequential for democracy. They shape political behaviour before, during and after elections. Election mindsets derive from other mindsets that we have about several other conditions and factors that shape elections. These include mindsets about power and politics, the role of the state on society, ethnicity, religion and political succession." (Waisbord, 2016, p6).

Indeed, these were further compounded by the ownership pattern and competing interests in the media industry. Personal interests and political sympathies of many of owners were mainstreamed into professional content of publications and broadcasting to demonize, advocate or manipulate public opinion. Even media organizations that claimed the materials easily betrayed non-partisanship on their pages or airwaves. Under the guise of performing their constitutional, structural and psychological responsibilities, many media professionals deliberately confused facts with feelings, masqueraded objective critical analyses with subjective political biases and, in many cases, engaged in defamatory contents that appeared as ordinary news, but were planted stories.

Misunderstanding of the roles of Journalists and the Media by Politicians: Journalists are finding it increasingly challenging to operate professionally and independently because of the misperception of the place and purpose of the Journalists in democratic settings by politicians. Many Sierra Leonean politicians want Journalists to be non-critical and report everything about them in a manner they so desire not necessarily based on professional judgments. Thus, the failure of such politicians to appreciate the professional and ethical requirements for news reporting led to frequent clashes with journalists, especially during elections.

\subsection{The role of Media in an election process}

The news media play an important role in elections and in ensuring a well-functioning democracy. Overall, the news media are responsible for ensuring accountability and transparency, informing citizens and adhering to journalistic standards. Media reports on the developments of an election campaign, provides a platform for parties/candidates to get their message out, provides a platform for the public to communicate their concerns and opinions, helps foster debate between parties and candidates, and advertises the election process to voters and reports on the results. With such an intervention from the media, there is high possibility for high political participation from the society. This is why in a well-functioning democracy, the electoral commission works in partnership with the media to ensure the successful outcome of an election. As a public institution, and given its responsibilities not only to disseminate electoral information and determine electoral results, but also to encourage civic electoral education, the electoral authority takes on a very public role. Its relationship with the media is therefore essential to the effective dissemination of its messages. However, unlike the electoral authority, the media is not, despite its public character, a public good. In Sierra Leone, the media is usually privately owned, has its own political interests, and therefore plays a crucial role shaping the pace of event in the electoral process. Its ability to reach wide audiences makes it a powerful actor capable of setting the mood for an election. The media determines who, what, and how they will cover an electoral process, the effect of which spills over onto the general public's opinion. As such, the relationship between the media and electoral authorities can become delicate and even contentious during the electoral campaign. Nonetheless, this relationship also has a potentially positive dynamic in which the media serve as an important auxiliary to electoral authorities in their efforts in ensuring transparency and credibility. Similarly, the media is an effective instrument for large scale dissemination of electoral information to the public. As a result, the management and coordination of this relationship is a critical aspect of the functioning of electoral authorities throughout societies across the globe, and an essential point for strengthening the electoral process. As such, it is imperative that, rather than disallowing the media from providing coverage during the electoral process, electoral authorities should formulate solutions or regulations to procure balanced coverage during electoral processes. In doing so, electoral authorities in each country should be mindful of the political context within which they and the media operate. This is why Dr. Rafael Roncagliolo of International IDEA and Dr. Raul Trejo of the Universidad Autónoma Nacional de México provided a general overview of this relationship and its implications for governance throughout the region. In addition, as Mr. Wesley Gibbings explained in his presentation on Media and Elections in the English-speaking Caribbean, media regulation is something that needs to be weighed carefully depending on the context, given potential negative effects on access to information. John Enright, Director of Media Relations at Elections Canada, explained in detail the media relations strategy of Canada's electoral authority, which has led to a streamlined, transparent relationship. 
Lastly, Gineen Beach of the U.S. Federal Electoral Commission, discussed the impact of the media on U.S. elections, with a special emphasis on the role of new technologies.

\subsection{The Impact of the Media on Election Campaign}

In a world where most of the youths are not interested in politics, it is of utmost necessity for the media to step up its effort in educating the voting population about the importance of elections. One of the problems of contemporary democracies is the high rate of political apathy, as there is a sharp decline of citizens' engagement and involvement in politics. It is apparent that several factors have contributed to such a process, including large scale economic and sociocultural transformations. However, the media and modern mediated political communication may also play an important role in effecting changes (Dahlgren, 2009). The issue of the effects of exposure to media and campaigns messages on civic engagement has generated an intense theoretical debate. While theories of media malaise argue that the impact of exposure to media and campaign messages on political involvement is negative, theories of mobilization contend that media and campaign effects are rather positive.

The impact of the media and campaign messages in an electioneering process on an emerging democracy cannot be overemphasized. It helps shaped the minds of the electorates on positive change and transformation in the midst of growing challenge of considerable partisan loyalties among the electorate as against national development.

However, other studies have established that media and campaign effects may depend on the type of media (usually distinguishing between electronic and print media), and the type of media content (whether news or entertainment) to which people are exposed. For example, Putnam $(1995,2000)$ argues that exposure to newspapers tends to increase social capital and political mobilization of citizens, in contrast to the negative consequences of watching entertainment programs on television. According to Putnam (1995), the decline of civic activism in most part of the world is partly due to the increase in the number of hours that individuals watch television, as it decreases time to interact with others. Exposure to television programs has also made people less trusting of others because such programs tend to overestimate the negative aspects of reality. The analysis of HoltzBacha (1990) on the German case concluded that political disaffection occurred mainly among individuals who were exposed to entertainment in the print and electronic media. In contrast, the consumption of news programs on television and reading the political section in newspapers fostered civic engagement. Similarly, the study of Newton (2000) on the United Kingdom shows that reading newspapers was strongly associated with higher levels of political knowledge, interest, and understanding. However, while television news tended to inform and mobilize; exposure to general television was weakly associated with indicators of political disaffection. Also, Shah, Mcleod \& Yoon (2001) found that while some entertainment content may cause a decrease in civic involvement, the use of news media is positively associated with it. Recent research confirms that television news has a positive impact on civic engagement. However, it is the exposure to news and political information on public television, rather than private commercial television, which is most effective in promoting the citizens' political engagement (Aarts \& Semetko, 2003; Strömbäck \& Shehata, 2010).

\subsection{Media in Conflict}

In order to have better understanding on the role of the media in peace building, its role in conflict management must also be established. There has been series of research works on how both local and international media can ignite violent conflict and thus, attracts international community's response to it. Media can be used to build a domestic constituency for war, to "sell" the war to the voting public (Bratic, 2006). The "CNN effect" dictates that the conflicts seen prominently on CNN will mobilize the Western public (particularly in the US) and put pressure on their governments to "do something". At the local level, several studies have revealed that media can directly incite violence, the most prominent case being the Radio-Television Libre des Milles Collines radio station in Rwanda, which broadcast the signal for the massacre to begin (Bratic, 2006). However, according to Bratic (2006), the relationship between media and conflict is complex and cannot be taken for granted. Civilians need access to reliable and timely information. This is often lacking in conflict contexts (Hieber, 2001; Sigal, 2009). Media can facilitate decision- making and help to create a sense of agency in chaotic contexts. Armed groups may restrict media access or use media to gain support for their positions (Sigal, 2009). Thus, the conflict environment creates a news vacuum; people only have access to rumor or partisan slogans (Dahlgren, P. 2009). Conflict can also restrict the media's ability to reach its audience: it can affect financial resources such as advertising revenue, and it can damage infrastructure and supply and delivery mechanisms (Sigal, 2009). The presence of international media may not be a remedy. While international news outlets inform their domestic audiences, local populations often have little access to such reports (Dahlgren, P. 2009). A balanced, accurate local media sector is crucial to meet the needs of citizens.

\subsection{Media in Peace Building}

The problem with peace is that the journalist instinct is always to look for the negative. While there has 
been extensive attention paid to the role of media in the instigation, support and reaction to violence, there has been comparatively little work done on the role of media in peace building (Bratic, 2006; Howard, 2002). There is an argument that the influence of the media on peace should be obvious, as the public receives almost all of its information about peace processes through the media, the framing of which can affect perceptions of the peace negotiations, and of the Other (Wolfsfeld et. al., 2004). The assumption has been made in the media development field that if media can fuel violence, it can promote peace, but there have been few studies to support this (Bratic, 2006).

The media's role in facilitating conflict can be directly related to their role in relating information on peace processes: if the media have played a significant role in mobilizing public support for conflict, it may be difficult for those same outlets to begin to advocate for peace. "No peace process begins with a culturally blank slate, but rather a slate filled with terrible images of death and destruction that remain an important element in collective memories" (Wolfsfeld et al., 2004). According to Howard et al., (2011), independent, professional media "have an almost innate potential for contributing to conflict resolution." They can counter misperceptions, rumor and propaganda, they frame the conflict, and they analyze the combatants, among other functions (Howard et al., 2011; Dahlgren, P. 2009).

Widespread public support for peace is necessary for a sustainable peace process. However, this public support must be based on knowledge of the political reality (IMS, 2016). Support for peace also depends on the public's trust in the media: a pluralist, independent media environment will be more conducive to peace building than one controlled by the government (IMS, 2016). The consensus among peace media scholars is that accurate, independent and balanced news reporting continues to be a crucial peace building tool because it can serve as a safeguard for democratic processes (Howard et al., 2011). Professional media can provide a diversity of viewpoints, aiding the public to make informed decisions (Howard et al., 2011). A free, independent media might serve as an early warning system, helping societies to avoid violent conflict (Howard et al., (011). Media have a watchdog function, holding public figures accountable to their constituencies (Howard et al., 2011). Media facilitate the working of civil society, including the monitoring of human rights abuses (Howard et al., 2011).

After the cessation of violence (negative peace), media might be used to rebuild relationships between communities by facilitating the positive peace described above. The absence of violence does not mean the absence of social injustice, and media can help highlight social inequalities. In this way, media may also help a community emerging from conflict from returning to violence, or play a preventative role before violence breaks out. Media helps to create an atmosphere conducive to peace by presenting information that is reliable, respects human rights and showcases diverse views (Howard et al., 2011). In order to fulfill this role, media must have access to information in the public interest rather than be reduced to providing opinion as opposed to information (IMS, 2016).

Attempts to use media as a peace building tool face multiple challenges. Underpaid journalists are more vulnerable to being bribed to produce biased reporting, which can undermine a free media sector (Howard et al., 2011). Restriction of editorial freedoms, security risks to media workers and content quality also affect the influence of the media (Hieber, 2001). For these reasons, the public may no longer trust the media, so the sector must rebuild its credibility (Howard et al., 2011; Hieber, 2001). Some peace negotiations may disassociate themselves from media scrutiny, and the media spotlight may endanger peace building in this context (Hieber, 2001; IMS, 2007). Censorship of conflict-supporting media is also controversial, with some arguing that free media are essential no matter the content (Bratic, 2006; Spicer, 1994). Finally, misunderstandings of the role of media in peace building may jeopardize support for media interventions: traditional Western concepts of journalistic values dictate that journalists report the facts, and that peace building implications ought not to be considered (Hieber, 2001). However, critiques of peace building do not take into account basic journalism training, which is perfectly in-line with conventional Western media standards. The role of media in peace building processes remains under-researched. While the above demonstrates that the field is gaining an understanding of media's influence, it is still evolving and remains complex (Howard et al., 2011). Media interventions alone are not enough to promote peace; media projects must work in tandem with other peace building initiatives to bring about change (Howard et al., 2011).

\subsection{Methodology}

This study adopted both qualitative and quantitative research approach. The target population in this study was journalists, editors, policymakers, lawyers and voters. The study was mainly conducted in Freetown, which is the capital city of Sierra Leone, densely populated with so many administrative centers including media houses. Also most of the government offices are still operating in Freetown and thus easy accessibility.

Primary and secondary sources of data were used to enhance the study. The instruments used for primary data collection were interview guides and questionnaires. According to Rasmussen \& Erik (2002), interview guides and questionnaires are useful for getting in-depth understanding of the issues under investigation rather than measuring those issues. In-depth interview method was used among media and electoral management professionals. 
This involved a one-on-one interview to elicit detailed answers on media role in conducting a peaceful election. Interviews were conducted at the convenience of the respondents with an aid of note taking. Data from the research was managed by editing, coding and tabulation. The Statistical Package for Social Sciences (SPSS) was used to analyze the research data. Descriptive analysis in the form of tables and correlation were used to present the findings for easy of interpretation of the data. Consequently, the study achieved its objectives of establishing the fundamental understanding of how mass media could be used to escalate conflicts and/or promote peace in an election by focusing on analysis of specific variables which enhances the understanding of the roles of media in conducting a peaceful election.

\subsection{Analysis of Results and Discussion}

This section contains findings of the investigation made to determine the role of media in creating peaceful election process in Sierra Leone. It provides the detailed analysis of gathered data, presentation of the findings together with illustrations and discussions on the same. It also provides the interpretation of the results.

Here we commences with analysis on the numerical data collected through the questionnaire. We administered 500 questionnaires in total, (50) questionnaires were administered to editors, (200) to Journalists and (250) readers and interview schedules to get in-depth data which is not possible to get by using a questionnaire in the Freetown Municipality. Of these, three hundred and eighty eight (388) that translates to $77.6 \%$ were filled completely by the respondents, seventeen (17) of the respondents hand in their questionnaires back without filling them, and ninety five (95) of the total respondents did not return their questionnaires. A breakdown of the questionnaire response rate is shown in table 1 and figure 1 below.

Table 1 Questionnaire Response rate

\begin{tabular}{|c|c|c|c|c|c|c|}
\hline \multirow{2}{*}{ Response } & \multicolumn{2}{|c|}{ Editors } & \multicolumn{2}{c|}{ Journalists } & \multicolumn{2}{c|}{ Readers } \\
\cline { 2 - 7 } & Frequency & $\%$ & Frequency & $\%$ & Frequency & $\%$ \\
\hline Responded & 43 & 86.0 & 157 & 78.5 & 188 & 75.2 \\
\hline Not responded & 7 & 4.0 & 43 & 21.5 & 62 & 24.8 \\
\hline Total & 50 & 100 & 200 & 100 & 250 & 100 \\
\hline
\end{tabular}

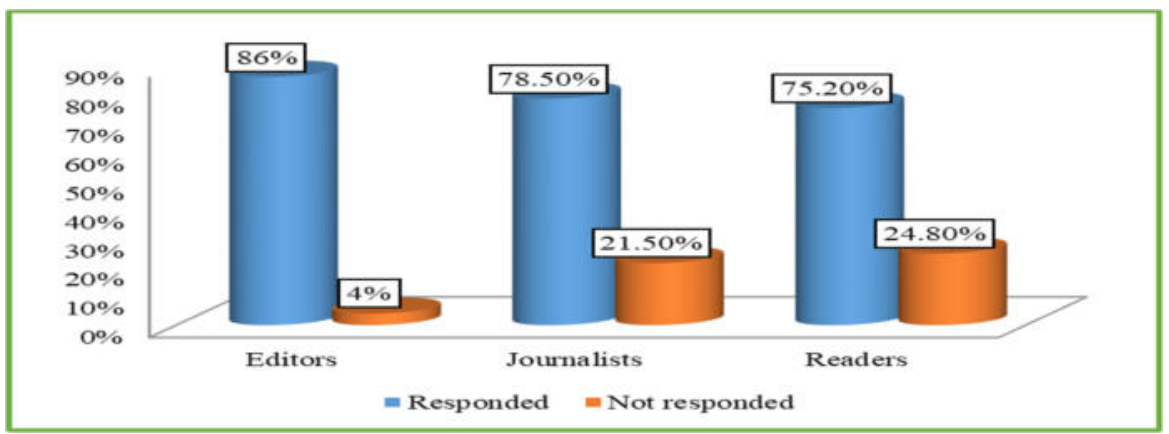

Figure 1 Response rate

\subsection{Media role in the 2018's General Elections}

This sub section provides answers to the research questions stated earlier in the introduction, and finally major investigations have been discussed under pertinent research questions. This section is therefore important in that it helped the researcher to come up with concrete results concerning the role of the media in the 2018 general elections in Sierra Leone. The data is summarized in form of tables, frequencies, percentages and charts.

Respondents were asked to state the hours they spent on media listening to radio, watching television, reading newspapers or browsing internet per day. The findings are presented in table 2 . It shows that $2.4 \%$ of respondents did not have time for media, 5.5\% spent less than 15 minutes on media, 20.1\% spent between $15-30$ minutes on media, $25.3 \%$ spent 30 minutes to 1 hour on media, $35.7 \%$ and $11.0 \%$ spent between $1-3$ hours and 3 6 hours respectively. This therefore means that more than $70 \%$ of respondents spent between 30 minutes to 6 hours on media. Thus respondents were able to listen to nearly all radio and television news broadcasts as well as read newspapers.

Table 2 Hours Spent On Media per Day

\begin{tabular}{|c|c|c|c|}
\hline & Frequency & Percent & Valid percent \\
\hline No time & 9 & 2.4 & 2.4 \\
\hline
\end{tabular}




\begin{tabular}{|c|c|c|c|}
\hline Less than 15 mins. & 21 & 5.5 & 5.5 \\
\hline $15-30 \mathrm{mins}$ & 78 & 20.1 & 20.1 \\
\hline $30 \mathrm{mins}-1 \mathrm{hr}$ & 98 & 25.3 & 25.3 \\
\hline $1-3 \mathrm{hrs}$ & 139 & 35.7 & 35.7 \\
\hline $1-6 \mathrm{hrs}$ & 43 & 11.0 & 11.0 \\
\hline Over $6 \mathrm{hrs}$ & $\ldots$. & $\ldots$. & 100.00 \\
\hline Total & 388 & 100.00 & $\ldots$. \\
\hline
\end{tabular}

Source: The Research Findings (2018)

\subsection{Media Advocating for Peace or Chaos}

Respondents were asked to provide some of the roles that media played during the 2018 general elections. Because of the variation in expression on same opinion, these roles were sorted, filtered, summarized and presented in table 3.

Table 3Media advocating for peace or chaos

\begin{tabular}{|c|c|c|c|c|c|}
\hline \multicolumn{3}{|c|}{ Media advocating for peace } & \multicolumn{3}{|c|}{ Media advocating for chaos } \\
\hline Role & Freq & $\%$ & Role & Freq & $\%$ \\
\hline Civil education & 161 & 49 & Promotion of propaganda & 167 & 51 \\
\hline Preaching peace & 265 & 81 & Platform for hate speech & 223 & 68 \\
\hline Unity call & 229 & 70 & $\begin{array}{l}\text { Bungling election } \\
\text { (errors in running }\end{array}$ & 131 & 40 \\
\hline $\begin{array}{l}\text { Informing public on negotiation } \\
\text { progress }\end{array}$ & 164 & 50 & $\begin{array}{l}\text { Misrepresentation } \\
\text { information }\end{array}$ & 167 & 51 \\
\hline Fair coverage of political campaign & 200 & 61 & Incitement & 236 & 72 \\
\hline Airing of peace negotiation & 299 & 70 & Airing violent scones & 200 & 61 \\
\hline $\begin{array}{l}\text { Airing of contentious areas during } \\
\text { negotiation }\end{array}$ & 203 & 62 & Partisan or taking political sides & 272 & 83 \\
\hline
\end{tabular}

Source: The Research Findings (2018)

These findings showed that media escalated conflict through promoting partisan interests and taking political sides $(83 \%)$ and incitement $(72 \%)$ among others. Conversely, media too played roles in de-escalating conflict through preaching peace $(81 \%)$, calling for unity $(70 \%)$ and airing of peace negotiations $(70 \%)$ among others. Some of the selected responses from respondents show that media escalated violence by involving listeners in the day to day announcements relating to chaos, playing music that could trigger violence and incite members of the community according to a respondent. In addition, another respondent stressed that media escalated violence through "news briefs that negatively reflected some communities". However, respondents also acknowledged positive contributions of media. A respondent said that media de-escalated conflict by "calling for voters to maintain peace as well as hosting peace ambassadors on their shows to neutralize propaganda in some regions". To further enrich the debate around this point, the researcher presented images that show how politicians were engaged in massive media campaign during the 2018 general elections (see figure 2). 


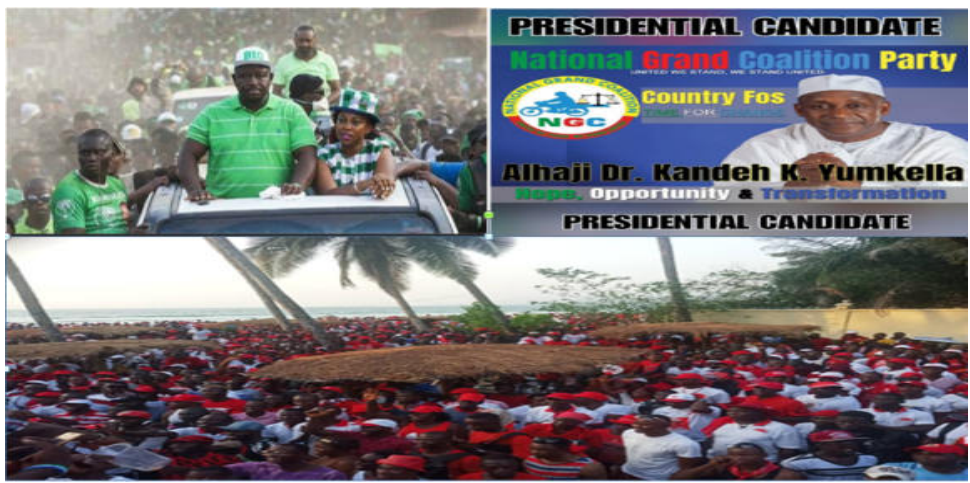

Figure 2 Politicians dominated media coverage in the electoral process

\subsection{Time Spent on Media, Main Source of Information and Favorite Media}

The main purpose of the study was to analyze the role of media in conflict management. This culminated to the crafting of three specific objectives. The first specific objective was aimed at establishing the media accessibility level and the types of media that cover the study area. Respondents were asked to state the time (hours) they spent on media, their main source of information and their favorite station or print media. Findings are summarized in table 4.

Table 4 Correlation: Time Spent on Media, Main Source of Information and Favorite Media

\begin{tabular}{|l|c|c|c|}
\hline Factors of analysis & Hours spent on media & $\begin{array}{c}\text { Source of information } \\
\text { (Media) }\end{array}$ & $\begin{array}{c}\text { Favorite station/print } \\
\text { media }\end{array}$ \\
\hline Hours spent on media & - & 0.092 & $0.161(* *)$ \\
\hline Source of information & 0.092 & - & $0.174(* *)$ \\
\hline $\begin{array}{l}\text { Favorite station/print } \\
\text { media }\end{array}$ & $0.161(* *)$ & $0.174(* *)$ & - \\
\hline $\mathrm{N}$ & 388 & 388 & 388 \\
\hline
\end{tabular}

The study findings revealed a positive but weak correlation of 0.092 between hours spent on media and main source of information, not statistically significant at $95 \%$ level of confidence; a positive and weak correlation of 0.174 between main source of information and favorite station, statistically significant at $95 \%$ level of confidence, and a correlation between source of information and hours spent on media of 0.161 , statistically significant at $95 \%$ level of confidence. Therefore, there appeared to be a weak positive and significant relationship between times spent on media, favorite station/print media, and source of information which could be interpreted as respondents spent more time listening to their preferred stations to gain information. Besides, results from interview with both security specialists and media practitioners revealed that African Young Voices (AYV) FM stations are popular amongst the populace and television has greater influence on listeners because they relay real time pictures.

The study finding reveals that radio is the main source of disseminating information of chaos in Sierra Leone. This is due to their ability to reach even the most remote corners of state, inexpensive broadcasting and cheap to acquire as compared to other mass media, thus eliminating the barrier of illiteracy to spreading news, information or propaganda. With an exceptionally high illiteracy rate, especially in rural areas, respondents' attitudes are influenced by the radio broadcasts appealing to them on the basis of their ethnic identities. These findings collaborate with the findings of the study by Fardon,. (1999).

Fardon, (1999) study titled „, Call to Genocide" showed that a large number of Rwandans could not read or write and, as a result radio was an important way for both the government and the rebels to deliver messages to the population. In addition, Bonior et al (1984) findings on the role of media in Vietnam War shows that roughly 50 million in the US watched television news each night and read newspapers on Vietnam War. These findings are contrary to Sierra Leone situation where preferred media is radio. This can be explained by the fact that radios are cheaper and portable compared to televisions. Equally, batteries, which are used to power radios, are readily available in shops and are relatively cheap and affordable compared to electricity and solar power which is expensive.

\subsection{The Role of Media}


Specific objective two was designed to establish the extent to which media could have escalated and/or deescalated violence during the 2018 general elections in Sierra Leone. In order to respond to this, respondents were asked whether media could have played a role during 2018 general elections and the role it played in relation to the post-election violence. $82.6 \%$ of respondents agreed that media played a role while $17.4 \%$ declined. Furthermore, $30.2 \%$ of respondents agreed that media escalated the conflict, $16.2 \%$ said that media de-escalated the conflict, $39.6 \%$ agreed that media performed both roles and $14 \%$ said that media did not perform any role as shown in table 5.

Table 5 Role of Media in during 2018 general election in Sierra Leone

\begin{tabular}{|l|c|c|c|}
\hline & Frequency & Percent & Valid Percent \\
\hline Escalated conflict & 117 & 30.2 & 30.2 \\
\hline Deescalated conflict & 63 & 16.2 & 16.2 \\
\hline Both roles & 154 & 39.6 & 39.6 \\
\hline None & 54 & 14.0 & 14.0 \\
\hline Total & 388 & 100.00 & 100.00 \\
\hline
\end{tabular}

Source: The Research Findings (2018)

These findings reveal that more than $80 \%$ of respondents agreed that media indeed played a role, with conflict escalation role ( $69.8 \%$ of respondents) outweighing de-escalation role $(30.2 \%$ of respondents). These findings fully agreed with media practitioners and security specialists, views of media roles during 2018 elections, which they subjectively put at $70 \%$ and $30 \%$ for conflict escalation and conflict de-escalation respectively.

Given these findings, media plays a pivotal influence in conflict escalation. Ideally, with its professional objectives of accuracy, impartiality and public responsibility as required by libertarian theory, media should be a contributor to peace building. However, these findings proved the contrary that during the 2018 general elections, the media played a negative role of conflict escalation. As argued by Wolfsfeld (2001), media sensationalizes conflict with simplistic reporting which reinforces stereotypes that reinforce elite consensus, and reflects its own environment of shared or isolated context.

In comparison to other studies, the findings are in line with the findings of Dallaire (2007), in analysis of Media Dichotomy, Case of Rwanda, that the local media, particularly Radio Television Libre des Mille Collines (RTLM) were literary used as a weapon to incite the killings of Tutsi. Conversely, the study by International Federation of Journalists (IFJ) on role of media affirms that media can not only help to defuse conflicts, but is also uniquely positioned to encourage coexistence and co-operation between people of different origins. This was not totally the case with the Sierra Leone media during 2018 general elections, according to these research findings. Additionally, practicing objective, fact-based reporting that avoids stereotypes or stirring up rumors, individual journalists and the media as a whole have a tremendous potential to contribute to understanding and bridgebuilding as confirmed by Dallaire (2007).

These findings that media played a role in conflict escalation negates the postulation of social responsibility theory of media reporting, which requires that media needs to assume both moral and legal responsibilities for all that they publish for the general good of the society without causing any harm. This escalation role caused conflict which led to the destruction of properties and loss of lives especially during the post-election period. Even though the social responsibility theory requires mass media to highlight injustices within the community and enlighten people on their rights and privileges, the predicament is that as people become more enlightened, the push for their rights through whatever means available, could lead to conflict as witnessed after the 2018 general elections in Sierra Leone though not at an alarming rate.

\subsection{Media and Hate Speech}

Findings on whether media could have encouraged hate speech during the 2018 general election showed that $61.3 \%$ of respondents agreed and $38.7 \%$ declined. The extent to which media promoted hate speech is shown in table 6 .

Table 6: Extent of Media Encouraged Hate Speeches

\begin{tabular}{|l|c|c|c|}
\hline & Frequency & Percent & Valid Percent \\
\hline Very large extent & 91 & 23.5 & 23.5 \\
\hline Large extent & 129 & 33.2 & 33.2 \\
\hline I don't know & 38 & 9.8 & 9.8 \\
\hline Small extent & 80 & 20.7 & 20.7 \\
\hline Very small extent & 5 & 1.2 & 1.2 \\
\hline
\end{tabular}




\begin{tabular}{|l|c|c|c|}
\hline None & 45 & 11.6 & 11.6 \\
\hline Total & 388 & 100.00 & 100.00 \\
\hline
\end{tabular}

Source: The Research Findings (2018)

Respondents reported that media encouraged hate speech to a very large extent, $33.2 \%$ said to a large extent, $9.8 \%$ indifferent, $20.7 \%$ said to a small extent, $1.2 \%$ said to a very small extent and $11.6 \%$ said none. This reveals that $52.8 \%$ of respondents agreed that media greatly encouraged hate speech during the 2018 general elections in Sierra Leone, $20.7 \%$ agreed to a small extent and $26.6 \%$ agreed that media did not encourage hate speech. Therefore, media encouraged hate speech to a large extent during the 2018 general elections in Sierra Leone. Additionally, Pearson correlation between media role in encouraging hate speech and the extent to which it contributed to post-conflict (chaos) in the 2018 general elections in Sierra Leone reveal a strong and positive correlation of 0.518 statistically significant at $95 \%$ level of confidence, as shown in table 7 .

Table 7: Pearson Correlation between Hate Speech and 2018 elections

\begin{tabular}{|c|c|c|}
\hline Factors of concern & $\begin{array}{c}\text { Do you agree that media can } \\
\text { encourage hate speech? }\end{array}$ & $\begin{array}{l}\text { Extent to which media could have } \\
\text { promoted hate speech during } 2018 \\
\text { elections }\end{array}$ \\
\hline $\begin{array}{c}\text { Do you agree that media can } \\
\text { encourage hate speech? }\end{array}$ & 1 & $0.586\left(^{* *}\right)$ \\
\hline $\begin{array}{c}\text { Extent to which media could have } \\
\text { promoted hate speech during } 2018 \\
\text { elections }\end{array}$ & $0.586(* *)$ & 1 \\
\hline $\mathrm{N}$ & 388 & 388 \\
\hline
\end{tabular}

This finding shows that media was used to spread hate speech. In comparison to findings on favorite media, it can be deduced that during the conflict FM radio stations broadcasting in ethnic languages urged their listeners to support positions taken by politicians from their ethnic communities. Specifically, a respondent claimed, "media used news briefs that negatively reflected some communities to promote hatred". For instance, media aligned to Citizens' radio acted as the mouthpiece of politicians calling for mass action against the government and other communities while AYV sympathetic media broadcast messages calling on their supporters to resist mass action and urged the government to protect Sierra Leoneans and their property. This is too supported by another respondent who claimed, "Media promoted propaganda through distorting truth" as witnessed in Calabatown debate.

In comparison to interviews with media practitioners and security specialists, they supported the finding that media encouraged hate speech to a large extent due to the fact that, according to a security specialist, most political parties e.g. APC and SLPP in Sierra Leone are tribal or regional oriented and people believe and follow what their leaders say. According to one media practitioner, hate speech can make recipients to feel that they are targeted and thus gang up to defend themselves, which results in conflicts. In addition, hate speech is encouraged through news headlines. Interview findings further revealed that most newspapers and radio stations used vivid key remarks by politicians and opinion leaders to construct their news headlines, sometimes with reference to past emotive events, selective reporting and common prejudicial stereotypes about groups. In addition, when the violence broke soon after the announcement of the presidential results in 2018, the community radio tended to give a lot of airtime and prominence to the violence through spiked and animated descriptions of what was happening. For instance, during the vote tally at some radio stations dedicated much of their time highlighting how SLPP was bundling votes, fights and quarrels between officials and politicians and amongst politicians. This promoted hatred amongst the already polarized citizen that resulted in violence after the elections. To curtail this, media practitioners observed during the interview that "Caution should be exercised by editors to ensure that both sides are given fair coverage as well as internal training, especially to field reporters, on conflict sensitive reporting”.

These findings negate the provision of libertarian theory which requires media to be immune from government controls and act as watchdog that guard against government abuses of power. Instead of condoning inflammatory hate remarks by politicians, media comfortably aired them, including political propaganda adverts directed towards opponents, thus allowing for manipulation by politicians. Conversely, social responsibility theory binds the practitioners to report objectively, truthfully and transparently as an obligation. This should not be misconceived to mean inciting remarks, as the same theory also obligates reporters to assume both moral and legal responsibilities for all that they publish for the general good of the society. 


\subsection{Media and Propaganda}

Findings on whether media promoted or provided a platform for propaganda during the 2018 general election showed that $71 \%$ of respondents said "Yes" and $29 \%$ said "No". The extent to which media promoted hate speech is shown in table 8 .

Table 8: Extent to which Political Propaganda led to 2018 post-election violence

\begin{tabular}{|l|c|c|c|}
\hline & Frequency & Percent & Valid Percent \\
\hline Very large extent & 94 & 24.1 & 24.1 \\
\hline Large extent & 96 & 24.7 & 24.7 \\
\hline I don't know & 46 & 11.9 & 11.9 \\
\hline Small extent & 132 & 33.8 & 33.8 \\
\hline Very small extent & 13 & 3.7 & 3.7 \\
\hline None & 7 & 1.8 & 1.8 \\
\hline Total & 388 & 100.0 & 100.0 \\
\hline
\end{tabular}

Source: The Research Findings (2018)

These results show that $24.1 \%$ of respondents agreed that media promoted political propaganda to a very large extent, $24.7 \%$ said to a large extent, $11.9 \%$ indifferent, $33.8 \%$ said to a small extent, $3.7 \%$ said to a very small extent and $1.8 \%$ said none. These revealed that $49.8 \%$ of respondents agreed that media promoted propaganda during the 2018 general elections to a large extent, $36.8 \%$ agreed to some extent and $14.2 \%$ agreed that media did not promote propaganda. Thus, media fairly promoted political propaganda during the 2018 general elections. Moreover, Pearson correlation between media promotion of political propaganda and the extent to which it contributed to the 2018 general elections revealed a positive but weak correlation of 0.386 and statistically significant at $95 \%$ level of confidence as shown in table 9 .

Table 9: Pearson Correlation between Media Propaganda and post- elections violence in 2018

\begin{tabular}{|l|l|l|}
\hline & $\begin{array}{l}\text { Can media be manipulated by } \\
\text { politician and opinion leaders? }\end{array}$ & $\begin{array}{l}\text { Extent to which this led to post- } \\
\text { elections violence in 2018 }\end{array}$ \\
\hline $\begin{array}{l}\text { Can media be manipulated by } \\
\text { politician and opinion leaders? }\end{array}$ & - & $0.386\left(^{* *}\right)$ \\
\hline $\begin{array}{l}\text { Extent to which this led to post- } \\
\text { elections violence in } 2018\end{array}$ & $0.386(* *)$ & - \\
\hline $\mathrm{N}$ & 388 & 388 \\
\hline
\end{tabular}

Some respondents corroborated this fact, for instance, a respondent said, "Media used exaggerations in reporting" while another claimed, "media used favoritism". These results were also supported by the analysis of media reporting and secondary data. As witnessed during 2018 general election, significant sections of the media houses were co-opted into political schemes of various political parties. They acted as propaganda mouthpieces for getting the messages of preferred candidates out to demonizing the opponents, according to the security specialist.

From the interview results, there are conflicting views. Security specialists believe that media encouraged or promoted controlled propaganda while media practitioners denied so and argued that they objectively reported what leaders said, and this fact could have caused conflicts. In support of his view, a media practitioner upholds that care is exercised in first publication to ensure validity and reliability of information before it's aired to avoid propaganda. Conversely, the security specialist argued that there could be factual accuracy in a single story that could not be substituted for the total truth. He stated that; "...factual accuracy can be misleading and thus can be used to promote political propaganda”. To deter this, one media practitioner says that news coverage and editors should seek alternative voices to a story and confirmation from relevant authorities before broadcasts.

The findings of the study that media fairly promote propaganda corroborate with the findings of Chretien, Spurk, \& Christopher (1995) in his study of the role of radio in Rwanda. Chretien et al (1995) findings reveal that from the opening days of the war, the government understood the importance of using media to rally Rwandans around the regime and used it to carry out a vigorous propaganda campaign. In support of this, Chretien et al (1995) findings reveal how RTLM reported the assassination of the Burundi president in a highly sensationalized way to underline supposed Tutsi brutality and heightened Hutu fear of Tutsi : "RTLM transcripts: 25 October; 20, 29, 30 November 2003" (International Criminal Tribunal for Rwanda, 2003). Other propaganda by RTLM were the repeated themes developed for years by the extremist Hutu that the Tutsis were "foreigners" hence had no claim 
to Rwanda aimed at increasing virulent propaganda to justify Tutsi killings.

\subsection{Conclusion and Recommendations}

From the results, it can be deduced that media played both roles of conflict escalation and de-escalation during the 2018 post-election violence. More specifically, media encouragement of hate speech contributed to 2018 post-election violence to a large extent; promotion of political propaganda contributed to 2018 post-election violence to a large extent; media escalated conflict through promoting partisan interests and taking political sides and; media withholding vital information contributed to 2018 post-election violence to some extent.

$\circ$ Based on the findings that there exists a significant variation amongst news reported by various media houses, the study recommends that media houses should adopt a common conflict reporting approach. This will help in mitigating the discrepancies in coverage to unearth areas of dispute and consensus objectively with a view of encouraging amicable solution to the matters at hand.

- The regulatory authorities should design a tailored regulatory mechanism for auxiliary FM stations different from the conventional ones. This is so because of their immense influence and popularity especially amongst the less educated members of society.

- Since media played both conflict escalation and conflict de-escalation roles during the 2018 general elections and subsequent 2018 post-election violence as per the findings of the study, the study recommends that media regulatory and law enforcers should design stern laws, rules and penalties for both media houses and personalities who use media for negative purposes.

- The study too recommends that local media reporters or journalists be trained on conflict reporting. Since conflict reporting is more challenging, most journalists were very unprofessional in the manner they handled the post-election violence reports as per the findings and therefore media training institutions should design study units on conflict reporting. The Sierra Leone Association on Journalism (SLAJ) that most deal with media issues should organize workshops and training on conflict reporting and management for its practitioners.

\section{References}

Aarts, Kees, and Semetko, Holli A. (2003). The divided electorate: Media use and political involvement. Journal of Politics 65: 759-84

Alozie, Emmanuel C in Thompson. The Media and the Rwanda Genocide, Fountain Publishers Ltd, 55 Nkrumah Road, Kampala, Uganda. (Caplan, G.): What Did They Say? African Media Coverage of the First 100 Days of the Rwanda Crisis: 2007, 211-230

Ankomah,(2001). Is Coverage of Africa racist? And why are we ignoring the DRC crisis? Reporting the World Round Table Report, 16th May, 2001

Bratic, V. (2006). Media Effects During Violent Conflict: Evaluating Media Contributions to Peacebuilding. Conflict and Communication Online, 5(1). Wolfsfeld, G. (2004). Communication Society and Politics: Media and the path to Peace. New York: Cambridge University Press.

Chrétien, J.P. (1995). La propaganda du génocide. In R. De La Brosse (ed.). Les médias de la haine. La Découverte, Paris, France: 22-55.

Dahlgren, P. (2009). Reconfiguring civic culture in the new media milieu. In J. Comer \& D. Pels (Eds.), Media and poliiical style: Essays on representation and civic culture (pp. 151-170). London: Sage

Dallaire, R. (2007). Shake Hands With the Devil: the Failure of Humanity in Rwanda. Random House, Canada.

Dahlgren, P. (2009). Reconfiguring civic culture in the new media milieu. In J. Comer \& D. Pels (Eds.), Media and poliiical style: Essays on representation and civic culture (pp. 151-170). London: Sage

Fardon, R. 1999. 'Ethnic Pervasion'. In T. Allen and J. Seaton (eds). The Media of Conflict: War Reporting and Representations of Ethnic Violence. Zed Books, London, UK.

Holtz-Bacha, Christina, and Norris, Pippa (2001). 'To entertain, inform and educate': Still the role of public television in the 1990s? Political Communication 18:2, 123-140

Hieber, L. (2001). Lifeline media: Reaching populations in crisis: A Guide to developing media projects in conflict situations. Geneva: Media Action International (MAI)

Howard, P. N., A. Duffy, D. Freelon, M. Hussain, W. Mari, and M. Mazaid. 2011. Opening Closed Regimes: What Was the Role of Social Media during the Arab Spring Project on Information Technology and Political Islam. Seattle: Department of Communication, University of Washington.

Holtz-Bacha, Christina (1990) Ablenkung oder Abkehr von der Politik? Mediennutzung im Geflecht politischer Orientierungen. Opladen: Westdeutscher Verlag.

Ibrahim, I., A., Ndisika, A., O., and Tejumaiye, A., (2003): Beyond Influence: Media and the 2018 Presidential Election. 
Isaac, M. S. (2016). For Election day influence, Twitter ruled social media. The New York Times.

Retrieved fromhttp://www.nytimes.com/2016/11/09/technology/for-election-day-chatter-twitterruled-socialmedia.html? $\mathrm{r}=0$ \&mtrref $=$ undefined

Kargbo, Abu Bakarr Hassan.(2010), Governance Processes in Sierra Leone From 1799-2009, The Write Room Press,Burnaby BC, Canada: 2010, 120, 122-123

Musa, Kamara., (2013): Media and the Process of Democratization in Sierra Leone. A Paper presented at a workshop on the media and Democracy in Sierra Leone. Organized by the INEC press corps hold at Kabala.

Macauley, Marcella in Zack-Williams.(2012), When the State Fails, Pluto Press, 345 Archway Road, London N6 5AA, International Actors and Democracy Promotion in Post-Conflict Sierra Leone: Time for Stock-Taking: 2012, 31-64

Mohamed Jalloh., (2012): Press and Politics in Sierra Leone.

Newton, Ken (1999). Mass media effects: Mobilization or media malaise? British Journal of Political Science 29, 577-59

Nwokeafor, Cosmas Uche in MeBayo, R. T., Onwumechili, C and Nwanko, N. R. (Ed.)(2000), Press and Politics in Africa, The Edwin Mellen Press, Ltd. Lampeter, Caredigion, Wales, United. Kingdom SA48 8LT: 124, Pan African News Agency: Conduit to Africa Press and Political System: 2000, 89183.

Okigbo, in M“eBayo, R. T., Onwumechili, C and Nwanko, N. R. (Ed.) (2000), Press and Politics in Africa, The Edwin Mellen Press, Ltd. Lampeter, Caredigion, Wales, United. Kingdom SA48 8LT: 124, Media, Civil Society and Politics in Africa: 2000, 63-65, 64-65, 75, 78

Putnam, Robert D. (1995). Tuning in, tuning out: The strange disappearance of social capital in America. PS: Political Science and Politics 28:4, 664-683

Putnam, Robert D. (2000). Bowling alone: the collapse and revival of American community. New York: Simon \& Schuster

Schramm, W. (1964),: Mass media and national development: The Role of Information in the Developing Countries. Stanford University Press, Stanford, California.

Sachs, Jeffrey. (2005) The End of Poverty, How We Can Make it Happen in Our Lifetime, Penguin Books Ltd. 80 Strand, London WC2R 0RI, England: 2005, 207

Shaw Ibrahim S. Historical frames and the politics humanitarian intervention: From Ethiopia, Somalia to Rwanda, Globalisation, Societies and Education, 2007, Vol. 5, No. 3, November: 351-371

.......... (2009) the ,us onlyee and ,us + them ${ }^{\text {ee }}$ frames in reporting the Sierra Leone war: Implications for Peace Journalism and Global Justice; the International Journal of Communications Ethics. Abramis Academic, ASK House, Northgate Avenue, Bury St. Edwards, Suffolk, IP32 6BB, UK:39-47

... (2012) Human Rights Journalism: Advances in Reporting Distant Humanitarian Interventions, Palgrave Macmillan St. Martin "es Press LLC, 175 Fifth Avenue, New York, NY 10010: 11-34, $105-$ 121

Strömbäck, Jesper, and Shehata, Adam (2010). Media malaise or a virtuous circle? Exploring the causal relationships between news media exposure, political news attention and political interest. European Journal of Political Research 49: 575- 597.

Shah, D. V., McLeod, J. M., \& Yoon, S. (2001). Communication, context, and community: An exploration of print, broadcast and Internet influences. Communication Research, 28(4), 464-506.

Silvio Waisbord. (2016). 'In journalism we trust? Credibility and fragmented journalism in Latin America'. In Mass Media and Political Communication in New Democracies, ed. Katrin Voltmer. London: Routledge.

Udensi, E., U. (2015): Social Media and Political Effects: A Case Study of the 2018 Sierra Leone Presidential Election. International Journal of social Science and Humanities Research. Vol. 3, Issue 2, pp 134-141.

Yaqub, N., and Sani, A., M. (2015): The Mass Media And the 2018 General Elections. Being Paper Submitted To the National Conference Organized By the Electoral Institute at The Independent National Electoral Commission, Freetown, June 2018 